\title{
Acinetobacter baumannii Biofilm: Intervening Factors, Persistence, Drug Resistance, and Strategies of Treatment
}

\author{
Acinetobacter baumannii Biyofilmi: Rol Oynayan Faktörler, Persistans, Ilaç Direnci ve Tedavi \\ Stratejileri
}

\author{
(1) Raja ELKHELOUI, (1) Asma LAKTIB, (1) Rachida MIMOUNI, (1) Aicha AITALLA, (1) Mohammed HASSI, (1) Abdellah ELBOULANI, \\ (1) Fatima HAMADI
}

Ibn Zohr University, Faculty of Sciences, Laboratory of Microbial Biotechnology and Plants Protection, Agadir, Morocco

\section{Abstract}

Acinetobacter baumannii (A. baumannii) is a Gram-negative opportunistic and nosocomial pathogen that is associated with most of the hospital epidemics. Its success can be directly attributed to its ability to survive under stressful hospital conditions (desiccation, nutrient starvation, and antimicrobial treatments). This survival ability results from the capacity of A. baumannii to form biofilms on the abiotic (polystyrene and glass) and biotic surfaces (epithelial cells and fungal filaments). The purpose of this review is to report different factors implicated in the biofilm formation of $A$. baumannii, notably biofilm-associated protein, $\mathrm{CsuA/BABCD}$ chaperone-usher pili system, poly- $\beta$ - $1,6-\mathrm{N}$-acetylglucosamine, outer membrane protein $A$, quorum sensing, surface properties, and growing conditions. This review will also discuss the relationship between biofilm formation and multidrug resistance, in addition to several strategies that can be useful in the prevention and treatment of $A$. baumannii biofilm.

Keywords: Acinetobacter baumannii, biofilm, genetic determinants, antibiotic resistance, treatment strategies

\section{Öz}

Acinetobacter baumannii (A. baumannii), hastane salgınlarının çoğuyla ilişkili Gram-olumsuz fırsatçı ve nozokomiyal bir patojendir. Bu patojenin başarısı, stresli hastane koşullarında (kuruma, besin yokluğu ve antimikrobiyal tedaviler) hayatta kalma kabiliyetine doğrudan bağlanabilir. Bu hayatta kalma yeteneği, $A$. baumanniı'nin cansız (polistiren ve cam) ve canlı yüzeylerde (epitel hücreleri ve mantar filamentleri) biyofilmler oluşturma yeteneğinden kaynaklanmaktadır. Bu derlemenin amacı; özellikle biyofilm-ilişkili protein, CsuA/BABCD şaperon-kılavuz pili sistemi, poli- $\beta$-1,6-Nasetilglukozamin, dış membran proteini $A$, çoğunluk algılanması, yüzey özellikleri ve büyüme koşulları gibi $A$. baumannii'nin biyofilm oluşumunda rol oynayan farklı faktörleri bildirmektir. Bu derlemede ayrıca, A. baumannii biyofilminin önlenmesi ve tedavisinde yararlı olabilecek çeşitli stratejilere ek olarak, biyofilm oluşumu ve çoklu ilaç direnci arasındaki ilişki tartışılacaktır.

Anahtar Kelimeler: Acinetobacter baumannii, biyofilm, genetik belirleyiciler, antibiyotik direnci, tedavi stratejileri

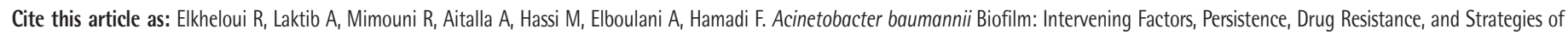
Treatment. Mediterr J Infect Microb Antimicrob. 2020;9:7. 


\section{Introduction}

The genus Acinetobacter includes a group of bacteria that are nonmotile, Gram-negative coccobacilli, displaying strict aerobic metabolism $^{[1]}$. This genus is catalase-positive, oxidase-negative, and shows a favorable growth at an incubation temperature of $37{ }^{\circ} \mathrm{C}^{[2]}$. Among its species, Acinetobacter baumannii ( $A$. baumannii) has emerged as one of the most troublesome pathogens for health care institutions. Over the last years, it has been remarked by its ability to upregulate and acquire the determinants of antibiotic resistance, thereby making it a challenge to the international health care community ${ }^{[2]}$. $A$. baumannii causes a range of infections, such as respiratory and urinary tract infections, meningitis, endocarditis, wound infections, and bacteremia, especially in the patients admitted in the intensive care units (ICUs) ${ }^{[3-5]}$. Infections caused by $A$. baumannii account for $1.6 \%$ of all healthcare-associated infections in both United States ${ }^{[6]}$ and Europe ${ }^{[7]}$; however, these rates are twice as high in Asian and the Middle Eastern countries ${ }^{[7]}$. Biofilm formation is an essential pathogenic mechanism in such infections. The exceptional resistance and survival in the hospital environment of $A$. baumannii may be explained by its potential to form biofilm ${ }^{[2,8]}$. Consequently, the clinical isolates of $A$. baumannii can survive for longer periods under the highly desiccated conditions on abiotic surfaces ${ }^{[9,10]}$ while forming biofilm on these layers. The purpose of this review is to report the biofilm formation capacity of $A$. baumannii on the surfaces in the hospital environment and its relationship with multidrug resistance, along with the involvement of multidrug resistance in the persistence of this nosocomial pathogen. This review will also present the essential factors involved in the biofilm formation mechanism, namely those related to the bacterium itself or to the surrounding environment, and finally the prevention and treatment strategies initiated by the scientific communities.

\section{Biofilm Formation}

\section{Definition}

The formation ability of biofilm is one of the major virulence factors of A. baumannii. The new definition of a biofilm is a microbial-derived sessile community characterized by the cells that are irreversibly attached to a substratum or interface or to each other. Those attached cells are embedded in a matrix of extracellular polymeric substances produced by them, and exhibit an altered phenotype with respect to the growth rate and gene transcription ${ }^{[11]}$.

\section{Biofilm Formation Steps}

Biofilm formation is a step-by-step process that includes three phases: adhesion, maturation, and dispersa ${ }^{[12]}$. In the adhesion phase, the planktonic cells attach to a surface via their appendages and may also get attached through other physical forces such as van der Waals forces or electrostatic interactions ${ }^{[13]}$. After primary attachment, the loose cells bind to the site through the molecular interactions between the host molecules (such as fibronectin) and bacterial surface arrangements (such as pili and fimbriae) ${ }^{[14]}$. After the microorganisms are attached to a biotic or an abiotic surface, this attachment becomes stable, and a process of multiplication and division of microbial cells starts, which is initiated through particular chemical signaling within the exopolysaccharides (EPS) ${ }^{[13]}$. In the biofilm maturation and dispersal phases, the bacteria produce a high number of EPS, which is the main material in the biofilm's three-dimensional structure. Thereafter, the interstitial voids are produced in the matrix to act as a circulatory system. This system distributes the important nutrients and removes the waste products from the communities of microcolonies in the biofilm ${ }^{[15]}$. The cells (single or clusters of cells) are then detached and colonized in the adjacent sites, respectively. Biofilm formation on the biotic and abiotic surfaces is an effective strategy to enhance the bacterial survival and persistence under stressed conditions ${ }^{[16,17]}$.

\section{A. baumannii Biofilm}

A. baumannii can form biofilms on several abiotic surfaces, such as polystyrene (a polymer that is commonly used in medical devices), polypropylene, polytetrafluoroethylene, and glass ${ }^{[18]}$. Additionally, several researchers have investigated the ability of $A$. baumannii to adhere and invade the biotic surfaces. The adherence of $A$. baumannii to erythrocytes ${ }^{[19]}$ and human bronchial epithelial cells ${ }^{[20]}$ is considered as the first step in the colonization process of this bacterium. The synergistic effect of an excessive growth on mucosal surfaces and medical devices, such as intravascular catheters and endotracheal tubes, can result in the biofilm formation of $A$. baumannii, which enhances the risk of infection of the bloodstream and airways ${ }^{[18]}$. Another work has also proved that the A. baumannii 19606-type strain adheres to and forms biofilms on the human alveolar epithelial cells and Candida albicans filaments, but not on the yeast cells ${ }^{[21]}$.

Researchers have demonstrated that $A$. baumannii is at least three times higher biofilm former at the solid-liquid interface than the other Acinetobacter species [number of isolates 48 (80\%)-42 (91\%) versus 1 (5\%)-8 (24\%), respectively] ${ }^{[22]}$. It is also hypothesized that the clinical strains can form stronger biofilms than the environmental strains ${ }^{[23]}$, and their ability to survive nutrient availability stress, desiccation, and antimicrobial therapies, is effectuated by the formation of biofilms on the medically relevant surfaces ${ }^{[24]}$. Ivankovic et al. have examined the susceptibility of biofilms of four hospitals and three environmental $A$. baumannii isolates on ceramics and glass to two disinfectants, namely, benzalkonium chloride and chlorhexidine. According to their research, the hospital 
and environmental isolates have the capacity to form biofilm on the two surfaces (glass, ceramics) ${ }^{[25]}$. Moreover, the biofilms of two isolates (hospital environments) on glass was destroyed by benzalkonium chloride (disinfectant) but on the ceramic surface, the survival rate of two isolates was higher after being exposed to disinfectant ${ }^{[25]}$. Furthermore, a study, which included 109 isolates of $A$. baumannii sampled in six cities of Southern Croatia in different medical institutions/departments and from different types of clinical samples, showed that the isolates collected from the ICUs and isolated from the respiratory samples were more able to form a biofilm as compared with the isolates from other departments and samples ${ }^{[26]}$.

\section{Intrinsic Factors of Biofilm Formation}

Bacterial biofilm, on both abiotic and biotic surfaces, is definitely not a simple adherence of bacterial cells to a surface. Adhesion and biofilm formation are well-orchestrated mechanisms responding to a large variation of factors, and some of them depend on strain (Table 1). In fact, 1,621 genes showed overexpression in biofilms, and 55 genes were exclusively expressed in $A$. baumannii sessile cells ${ }^{[27]}$.

\section{Biofilm-associated Protein (BAP)}

Loehfelm et al. ${ }^{[28]}$ were the first ones to identify BAP in $A$. baumannii, it is a protein of cell surface analogous of that of Staphylococcus. Biofilm-associated protein is secreted via a type 1 secretion system ${ }^{[29]}$ and involved in the formation and maturation of A. baumannii biofilm. It plays a role in the cellcell adhesion and the development of higher-order structures on the medically relevant materials, such as polystyrene and titanium ${ }^{[28]}$. The scanning electron microscope analyses of biofilm have shown that the three-dimensional tower structure and water channel formation required BAP on the medically relevant surfaces (e.g., polypropylene, polystyrene, and titanium) [30]. However, BAP-deficient cells remain predominantly in a single layer, thereby constituting a few areas of cellular aggregates $^{[30]}$. Moreover, the same research showed that BAP increases the adherence of $A$. baumannii by a comparative study of A. baumannii strain 307-0294 and A. baumannii 3070294 BAP-deficient mutant ${ }^{[30]}$. A. baumannii strain 307-0294 associated with the normal human bronchial epithelial cells and normal human neonatal keratinocytes at a significantly higher percentage than A. baumannii 307-0294 BAP-deficient mutant $(p<0.02)$, probably by improving the bacterial cell surface hydrophobicity ${ }^{[30]}$. Additionally, this protein is conserved among an amount of 98 Acinetobacterstrains ${ }^{[28]}$; proving its importance in adhesion and biofilm formation.

\section{CsuA/BABCD Chaperone-usher Pili Assembly System}

Pili are homo- or heteropolymeric protein structures present on the surface of bacteria ${ }^{[31]}$, and play a key role in the adhesion of microorganisms ${ }^{[32]}$. Csu pili are a type 1 chaperone-usher pilus system encoded and produced by a majority of $A$. baumannii strains $^{[33]}$ and regulated by the BfmRS two-component regulatory system ${ }^{[34]}$. These pili are not required for the adhesion on the biotic surfaces, such as human epithelial cells ${ }^{[35]}$, but are essential for the biofilm formation and maintenance on the abiotic surfaces, including polystyrene. Csu operon-positive $A$. baumannii isolates were able to form a biofilm significantly more mature than those of Csu operon-negative isolates, thus proving the importance of the Csu operon in the biofilm formation ${ }^{[36]}$. Interestingly, most $A$. baumannii strains appear to carry the CsuA/BABCDE locus (a group of genes coding the different units of the type 1 chaperone-usher pilus system), but a subset of clinical isolates may have lost it ${ }^{[37]}$. Consequently, these pili may not be critical for biofilm formation and maintenance in all

Table 1. Intrinsic and extrinsic factors implicated in the A. baumannii biofilm formation

\begin{tabular}{|c|c|c|c|}
\hline Intrinsic factors & Functions & $\begin{array}{l}\text { Extrinsic } \\
\text { factors }\end{array}$ & Examples \\
\hline \multirow[t]{3}{*}{ BAP } & Cell-cell adhesion ${ }^{[28]}$ & \multirow{6}{*}{$\begin{array}{l}\text { Surface } \\
\text { properties }\end{array}$} & Surface nature \\
\hline & Water channel formation and three-dimensional & & Roughness \\
\hline & tower structure $^{[30]}$ & & \multirow{4}{*}{$\begin{array}{l}\text { Physico-chemical properties of the } \\
\text { surface } \\
\text { Presence of protein films }\end{array}$} \\
\hline \multirow{2}{*}{$\begin{array}{l}\text { CsuA/BABCD chaperone- } \\
\text { usher pili assembly system }\end{array}$} & Biofilm formation and maintenance on abiotic & & \\
\hline & surfaces $^{[35]}$ & & \\
\hline PNAG & Capacity and thickness of biofilm formation ${ }^{[39]}$ & & \\
\hline \multirow[t]{2}{*}{ OmpA } & Interaction with both human epithelial cells and & \multirow{5}{*}{$\begin{array}{l}\text { Growing } \\
\text { conditions }\end{array}$} & $\mathrm{pH}$ \\
\hline & $\begin{array}{l}\text { Candida albicans filaments and attachment step } \\
\text { of } A \text {. baumannii on plastics }\end{array}$ & & Osmolarity \\
\hline Beta-lactamase PER1 & $\begin{array}{l}\text { Adhesion of } A \text {. baumannii to both biotic and } \\
\text { abiotic surfaces }^{[45]}\end{array}$ & & Oxygen \\
\hline \multirow[t]{2}{*}{ Quorum sensing system } & \multirow{2}{*}{$\begin{array}{l}\text { Activate/regulate gene expression of virulence } \\
\text { factors including biofilm formation }{ }^{[48]}\end{array}$} & & $\begin{array}{l}\text { Hydrodynamics of the fluid } \\
\text { Temperature }\end{array}$ \\
\hline & & & Environmental nutritional conditions \\
\hline
\end{tabular}

BAP: Biofilm-associated protein, OmpA: Outer membrane protein A, PNAG: Poly- $\beta$-1,6-N-acetylglucosamine 
the strains or that other pili systems may functionally replace them ${ }^{[37]}$. GracSA, a second two-component system, was shown to moderately control the Csugene expression; thus, it indirectly affects biofilm formation ${ }^{[37]}$. Furthermore, de Breij et al. ${ }^{[35]}$ have stated that $A$. baumannii ATCC 19606 strain produces a short and thin independent CsuA/BABCDE operon pili that may be involved in the biotic surface adhesion such as the human respiratory cells.

Poly- $\beta-1,6-\mathrm{N}$-acetylglucosamine (PNAG)

Poly- $\beta-1,6-N$-acetylglucosamine, encoded by the pgaABCD gene cluster, is one of the important structures for biofilm formation in microorganisms (Gram-negative and Grampositive ${ }^{[38]}$. Biofilm development and maturation of the clinical A. baumannii isolates also depend on the capacity to produce and secrete this substance as a major component of the biofilm EPS matrix $^{[38]}$. The expression of pgaB was much higher in a clinical A. baumannii strain than that of an environmental strain, and was associated with an increase in the capacity and thickness of biofilm formation ${ }^{[39]}$. Another study has revealed that the deletion of pgaABCD induced the absence of PNAG ${ }^{[38]}$. Moreover, it induces the loss of the strong biofilm phenotype, which was re-established after complementation ${ }^{[38]}$. Consequently, the antibodies against $\mathrm{PNAG}^{[38]}$ can eliminate $A$. baumannii in the opsonophagocytosis assays, suggesting that PNAG might be a potential vaccine target ${ }^{[40]}$.

\section{Outer membrane protein A $(0 \mathrm{mpA})$}

The OMP of Gram-negative bacteria have been associated with antibiotic resistance, adaptation, and pathogenicity in the host cells. Some OMPs of the OmpA family have been characterized in the Acinetobacter strains and are one of the major OMPs in the genus ${ }^{[41]}$. The $0 \mathrm{mpA}$ of $A$. baumannii is a real virulence factor since it is involved in the adhesion and invasion of epithelial cells. These proteins cause their apoptosis by targeting the mitochondria, which leads to the spread of the bacterium through the mucosa. This bacterium is thus disturbed, and it systematically induces infection ${ }^{[41-43]}$. Outer membrane protein A plays a crucial role in the biofilm formation by promoting the cell surface and cell-to-cell adhesion on both the biotic and abiotic surfaces. This trimeric porin of $38 \mathrm{kDa}$, acting as a general diffusion pore of size of $1.3 \mathrm{~nm}$, plays a role in the interaction of the pathogen with both the human epithelial cells and Candida albicans filaments as well as in the attachment step of $A$. baumannii on plastics ${ }^{[2,42,44]}$.

\section{Beta-lactamase PER1}

Lee et al. ${ }^{[4]}$ have shown that the adhesion of $A$. baumannii is enhanced by the presence and expression of the blaPER-1 gene to both the biotic surfaces, such as bronchial epithelial cells (initiation of host-pathogen interaction leading to pathogenesis), and to the abiotic surfaces, such as plastic, even if the mechanism by which that occurs remains unstable. On the contrary, only 2 out of 11 human isolates with the blaPER-1 gene are robust biofilm formers as compared with the isolates without this genetic determinant ${ }^{[46]}$. Therefore, these results raise to question the actual intervention of blaPER-1 expression in the biofilm formation ${ }^{[46]}$. This observation will be discussed later in this manuscript.

\section{Quorum sensing (OS) system}

In wild life, bacteria share a close association with eukaryotic hosts and other bacteria. Constantly, it is essential to monitor and communicate with neighbors. Hormone-like molecules (autoinducers) are produced by bacteria as the signals to sense the cell density and activate adaptations by $0 \mathrm{~S}^{[47]}$. Autoinducers act by activating/regulating gene expression by binding to transcriptional regulatory proteins in the organism ${ }^{[48]}$. Researchers have linked OS system with different processes, notably the production of virulence factors, motility, nodulation, plasmid transfer, antibiotic production, bioemulsan production, bioluminescence, and biofilm formation ${ }^{[49-51]}$.

Abal and abaR are the QS genes acquired horizontally from Halothiobacillus neapolitanus and expressed in A. baumannii ${ }^{[52]}$. This $\mathrm{OS}$ system involves the AbaR receptor protein that forms a complex with the Abal (auto-inducer synthase)-generated $\mathrm{N}$-(3-hydroxydodecanoyl)-L-homoserine lactone that regulates the virulence factors (e.g., biofilm formation and surface motility) ${ }^{[53]}$. Researchers have found that an auto-inducing OS molecule controlled biofilm formation among the clinical isolates of Acinetobacter spp. ${ }^{[54]}$. Abal was present among the isolates that produce the $\mathrm{QS}$ signaling molecules and a mutation in the abal influenced biofilm-forming capabilities Acinetobacter spp. ${ }^{[54]}$. Some researchers investigated the association between the effect of $a b a R$ on the biofilm formation and drug resistance of $A$. baumanni[i[5]. The upregulation of the expression of bfmS and bfmR genes is linked to the OS molecules, thereby enhancing the ability of $A$. baumannii to form biofilm on the abiotic surfaces ${ }^{[56]}$. Furthermore, the $\mathrm{OS}$ system can also be a potential target for a new drug by developing many quorum quenching (00) strategies targeting the AHL synthase enzyme, the $\mathrm{AHL}$ binding receptor, and the $\mathrm{AHL}$ itself ${ }^{[57]}$.

\section{Extrinsic Factors of Biofilm Formation}

\section{Surface Properties}

In the case of adhesion to the abiotic surfaces, $A$. baumannii can form and develop a high biomass biofilms on different surfaces such as stainless steel, polystyrene, and polycarbonate (a thermoplastic material that is often used to construct the medical devices) ${ }^{[58]}$. Several factors may affect the attachment of bacteria to these surfaces and the formation of a biofilm 
(Table 1), such as roughness, the physico-chemical properties of a surface, and the presence of protein films. All the materials used in the manufacturing of implantable medical devices are described as biomaterials. Hundreds of polymers are currently used separately or combination with the manufacturing thereof. As examples, the latex catheters are inexpensive and have a good elasticity, but tend to be more prone to bacterial adhesion ${ }^{[59]}$. In the case of silicone, it is the standard in terms of biocompatibility and is also mild, non-irritating, and clinically stable, which is ideal for long-term use ${ }^{[59]}$, but silicone is still very sensitive to biofilm formation ${ }^{[60]}$. The bacterial cells have a negative charge on their cell membrane but this charge is more or less important from one strain to another. The surface charge of the material can be varied by the $\mathrm{pH}$ and ionic composition of the surrounding solutions as well as by protein adsorption, which occurs during the early stages of adhesion. This adhesion increases with the hydrophobicity of the support ${ }^{[61,62]}$. Indeed, the roughness of the surface is important as the colonization by microcolonies ${ }^{[63]}$. The prior presence of a protein film on a biomaterial such as blood, tears, urine, saliva, interstitial fluid, and respiratory secretions affects the attachment of bacteria to its surface and promotes the formation of biofilm ${ }^{[64]}$.

\section{Growing Conditions}

Growing conditions are important characteristics that can strongly modify the adhesion of organisms. pH, osmolarity, iron concentration, and oxygen are important to consider in the biofilm formation process ${ }^{[65]}$. The hydrodynamics of the fluid also affects the biofilm formation. Indeed, depending on the position of the material in a fluid, it will be more or less exposed to turbulence. The zone of less turbulence, away from the laminar flow, is called the fixing zone. It is precisely in this area where it is easier for the microorganisms to settle on a surface, since they are less subjected to the forces exerted by the fluid ${ }^{[11]}$.

The growth temperature is also an important factor of biofilm formation. Acinetobacter spp. biofilm formation was more important at $25{ }^{\circ} \mathrm{C}$ than at $37{ }^{\circ} \mathrm{C}^{[22]}$. However, the optimal conditions for biofilm formation by A. baumannii were reported to be $30{ }^{\circ} \mathrm{C}$ at a $\mathrm{pH}$ of 7.0 in a medium containing sodium chloride at a concentration of $5 \mathrm{gL}^{-1[1]}$. Another study showed that the biofilm formation of $A$. baumannii was high at $28^{\circ} \mathrm{C}$ because of the upregulation of certain BAPs such as Csu and iron uptake proteins on the plastic surfaces ${ }^{[6]}$. Additionally, Eze et al. ${ }^{[67]}$ demonstrated that $A$. baumannii biofilm formation is enhanced when nutrient-poor medium and $26^{\circ} \mathrm{C}$ are used with or without agitation.

Interestingly, the A. baumannii ATCC 17978 strain produced little or no biofilm on the glass surfaces when it was incubated under blue light, whereas a normal biofilm was observed when the cells were incubated in the darkness ${ }^{[68]}$. This finding is mediated by the BlsA photoreceptor protein, with a $\mathrm{N}$-terminal bluelight-sensing that uses the flavin domain. The mechanisms of light signal transduction and gene expression control of BlsA are not yet known. However, the diverse transcription of $b / s A$ at 37 ${ }^{\circ} \mathrm{C}$ and $28{ }^{\circ} \mathrm{C}$ differentially affects the response of $A$. baumannii biofilm to the light. In addition, this response seems to have a global effect on $A$. baumannii physiology, disturbing biofilm formation and also motility and virulence ${ }^{[68]}$.

Environmental nutritional conditions affect the growth and lifestyle of a bacterial population. Indeed, in a static environment, the concentration of nutrients must be high so that a biofilm can be formed; however, this is not the case for a hydrodynamic environment ${ }^{[69]}$. Some sources of carbon and cations ( $\mathrm{Na}^{+}$sodium, $\mathrm{Ca}^{2+}$ calcium, and $\mathrm{Fe}^{3+}$ ferric ion) also affect the formation of a biofilm ${ }^{[11,70]}$. The biofilm formation of $A$. baumannii was reported to be affected by environmental stress and growth conditions ${ }^{[7]}$. A. baumannii cultured in a glucosebased medium and exposed to the sub-inhibitory concentrations of antibiotics (e.g., imipenem) can lead to an increased iron uptake and induce biofilm formation in a clinical multidrugresistant phenotype ${ }^{[7]}$. Five well-characterized A. baumannii strains, cultured in three iron-poor media depending on the strain, have shown different levels of biofilm growth ${ }^{[72]}$. In the tryptic soy broth dialysate, all the strains produced an increased biofilm as compared with other iron-poor media. Therefore, biofilm formation in A. baumannii depends on strain ${ }^{[72]}$. Also, a significant reduction showed by $A$. baumannii clinical isolates in the adhesiveness and biofilm formation ability on the biotic and abiotic surfaces (i.e., human respiratory epithelial cells and plastics, respectively) when grown with an iron-chelating agent $^{[20,45]}$

Ethanol had also been an effect on biofilm formation on the abiotic surfaces. In fact, the presence of ethanol increase the production of proteins involved in the lipid and carbohydrate anabolism, thereby raising the carbohydrate biofilm content, decreasing bacterial motility and enhancing biofilm formation ${ }^{[73]}$.

\section{Biofilm and Antibiotic Resistance}

A. baumannii is naturally resistant to a large spectrum of antibiotics ${ }^{[74]}$. In the last two decades, because of the widespread use of antibiotics, multidrug-resistant (MDR) strains, which are defined as an acquired non-susceptibility to at least one agent in three or more antimicrobial categories and extensively drugresistant (XDR) strains, which are defined as non-susceptibility to at least one agent in all but two or fewer antimicrobial categories (i.e., bacterial isolates remain susceptible to only one or two categories) have emerged. A large number of reports have suggested the worldwide emergence of $A$. baumannii as a critical problem ${ }^{[7,76]}$. Laktib et al. ${ }^{[77]}$ conducted a study in two ICUs (adult and neonatal ICUs) of The Regional Hospital Center of Agadir, 
Morocco and showed that the most frequently isolated strains were of A. baumannii (82.8\%). Multidrug-resistant A. baumannii strains were the most dominant in the adult ICU (42.8\%) and held the second position after the extended spectrum betalactamase (ESBL)-producing Enterobacteriaceae strains (Table 2) in the neonatal ICU ${ }^{[77]}$. The use of broad-spectrum antibiotics and the transmission of strains among patients are considered as the selective pressures that lead to the emergence of MDR A. baumannii ${ }^{\text {[78]. }}$ Multidrug-resistant strains are often isolated from the patients treated with broad-spectrum antibiotics and those with compromised immunity ${ }^{[79]}$. They exhibit various mechanisms that resist multiple classes of antibiotics, especially the production of antibiotic degradation/modification enzymes, active drug efflux pumps, decreased permeability, biofilm formation, and modification in the drug targets ${ }^{[17]}$. The main common mechanism responsible for carbapenem resistance in $A$. baumannii is the production of carbapenemases, including class $B$ metallo- $\beta$-lactamases and class $D \beta$-lactamases (oxacillinases) ${ }^{[80,81]}$. The emergence of MDR and XDR A. baumannii leads to the application of limited and potentially toxic alternatives (e.g., colistin, polymyxin B) for treatment, which are correlated with poor outcomes in the patients ${ }^{[82]}$.

The association between biofilm formation and antibiotic resistance phenotypes still disputable. Some studies have demonstrated that biofilm formation appeared to be positively correlated with multidrug resistance ${ }^{[46,83,84]}$. A study has already reported a positive correlation between the drug resistance and biofilm formation in the form of ESBL blaPER-1 gene among the $A$. baumannii isolates ${ }^{[84]}$. At least $92 \%$ of the biofilmforming isolates of clinical strains isolated from patients with nosocomial infections in three hospitals in Tehran were MDR ${ }^{[84]}$. Srinivasa Rao et al. ${ }^{[46]}$ mentioned a significant correlation between multidrug resistance and biofilm formation. However, the presence of blaPER-1 is more critical for cell adhesion than the formation of bacterial biofilms on the abiotic surfaces ${ }^{[47]}$. It was observed that the cell adhesiveness and biofilm formation on plastic is higher in strains with the blaPER-1 gene than in those without this genetic determinant ${ }^{[46]}$. A significant correlation was determined between multidrug resistance and biofilm formation of environmental and clinical isolates ${ }^{[23]}$, namely, clinical isolates had a higher biofilm formation ability than the environmental isolates ${ }^{[23]}$. The MDR clinical isolates of $A$. baumannii carrying the blaPER-1 gene were reported to adhere to the epithelial cell surface and form biofilm in polystyrene plates higher than those without it ${ }^{[45]}$. The majority of the clinical Acinetobacter spp. isolates from intensive and nonintensive tertiary care hospital units in Bangladesh, especially those isolated from the ICU samples, were reported as MDR and biofilm producers ${ }^{[85]}$. It was found that $84.7 \%$ of the 72 clinical isolates of $A$. baumannii isolated from India were resistant to piperacillin, $80.5 \%$ to amikacin, $72.2 \%$ to ciprofloxacin, $66.6 \%$ to ceftazidime, $36.1 \%$ to imipenem, $25 \%$ to ampicillin-sulbactam, whereas $62.5 \%$ of the isolates produced biofilm ${ }^{[86]}$. Badave and Kulkarni ${ }^{[86]}$ established that 40 strains of 72 A. baumannii tested strains were considered as both MDR and biofilm formers with a significant correlation $(p=0.0004)$.

About $35.5 \%$ of the isolates from a tertiary care hospital in Mexico were resistant to meropenem, 50.7\% to imipenem and $86 \%$ to ciprofloxacin, ceftazidime, and cefotaxime ${ }^{[75]}$. Of these isolates, $25.7 \%$ and $28.3 \%$ were positive for the blaOXA-72 and blaOXA-58 genes, respectively ${ }^{[75]}$. The work also associated biofilm production with resistance to imipenem $(p=0.002)$ [75]. The ability to produce biofilm in relation to antibiotic resistance in A. baumannii was also demonstrated by Kaliterna et al. ${ }^{[26]}$. Ampicillin/sulbactam-, carbapenems-, and amikacinresistant strains were found to be biofilm-negative while those were susceptible and intermediately susceptible to ampicillin/sulbactam, carbapenems, and amikacin were biofilm producers $^{[26]}$.

Because of their capacity to extrude the majority of antibiotics from within the cells to the extracellular environment and also in the biofilm formation, efflux pumps have a important implication in antibiotic resistance ${ }^{[87]}$. It was demonstrated that the synthesis and transport of auto-inducer molecules is linked to the AdeFGH efflux pump during the biofilm formation of $A$. baumannili ${ }^{[88]}$, and in the presence of sub-inhibitory concentrations of tigecycline, the downregulation of the AdeFGH efflux pump resulted in a reduction in A. baumannii biofilm ${ }^{[89]}$. Moreover, AbaF, an efflux transporter of Escherichia coli, was cloned and expressed from an efflux-deficient strain Escherichia coli KAM32 ${ }^{[90]}$. After its disruption in A. baumannii by using a homologous recombination, an increase in fosfomycin susceptibility and a decrease in biofilm formation and virulence were observed ${ }^{[00]}$.

Table 2. Prevalence of multidrug-resistant bacteria isolated from adult and neonatal intensive care units ${ }^{[77]}$

\begin{tabular}{lllll}
\hline \multicolumn{7}{l}{ MDR bacteria } & & & Total \\
\hline Services & ESBL-producing Enterobacteriaceae & MDR A. baumannii & MDR S. maltophilia & 14 \\
\hline AICU & $5(35.7 \%)$ & $6(42.8 \%)$ & $3(24.4 \%)$ & 20 \\
\hline NICU & $12(60 \%)$ & $8(40 \%)$ & 0 & 34 \\
\hline Total & - & - & - & \\
\hline
\end{tabular}

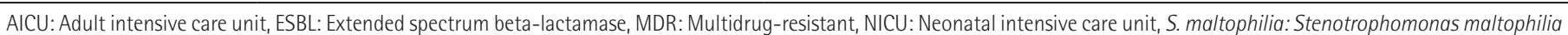


This relationship may be because of the high production of EPS in A. baumannii. This EPS production creates a protective barrier that prevents the antibiotic penetration leading to the development of resistance. Furthermore, there are differences in the physiology of the cells inside the biofilm that produces an increased drug resistance ${ }^{[01]}$. Also, the horizontally genes transfer between bacterial cells is enhanced in biofilm mode, thereby facilitating the spread of antibiotic resistance ${ }^{[11]}$. Acinetobacter is known to exhibit an extraordinary ability to acquire foreign DNA ${ }^{[22]}$. A study confirmed that blaNDM-1 could easily be transfer to strong biofilm-producing Pseudomonas aeruginosa and $A$. baumannii by Enterobacteriaceae strains in the environment ${ }^{[93]}$. In general, the biofilm compartment is highly resistant to antibiotics because of the reduced diffusion of antibiotics into the biofilm, the presence of persisted cells, slow growth rates, low metabolism of cells that exist deep within the biofilm, increased horizontal transfer of resistance genes (due to cell vicinity), and a high rate of mutations (in response to stress) $)^{[94,95]}$.

Contradictorily, when the MDR A. baumannii strain, collected from a Chinese hospital, showed a strong biofilm-forming ability, the resistance to levofloxacin, cefepime, and gentamicin was significantly decreased ${ }^{[96]}$. Studies have also demonstrated little or no biofilm-producing capacity by resistant $A$. baumannii ${ }^{[1,97]}$. Colistin reduces biofilm formation on the urinary catheter surfaces at sub-inhibitory concentration ${ }^{[1]}$. It was shown that the isolates pre-treated with colistin had a significant reduction in their adhesion ability $(p<0.05)^{[1]}$. The cultures treated with 0.5 minimum inhibitory concentration (MIC), as compared to those treated with $0.25 \mathrm{MIC}$, revealed decreased biofilm formation $(p<0.05)^{[1]}$. In total, 249 isolates of 272 clinical isolates of $A$. baumannii had a biofilm formation ability, of which 63 were stronger biofilm formers than the A. baumannii strain type ATCC $19606^{[97]}$. Isolates with high levels of resistance were weak biofilm formers, whereas the majority of isolates that formed the biofilms were non-MDR ${ }^{[97]}$. On the contrary, the over-expression of AdeABC efflux pump largely contributes to multidrug resistance, an altered membrane composition and decreased biofilm production in A. baumannii ${ }^{[98]}$.

Through all these facts, it is necessary to more understand the bacterial mechanisms to keep a balance between biofilm formation and antibiotic resistance, and also those implicated in the ability to achieve high levels of biofilm-specific resistance despite producing weak biofilms ${ }^{[97]}$.

\section{Biofilm and Persistence of $A$. baumannii}

In addition to antibiotic resistance, biofilms offer protection against the infected host's immunity to the bacteria. The size of biofilms is firstly an important obstacle to the phagocytosis process. Phagocytic cells release enzymes that have a very little effect on the biofilm ${ }^{[99]}$. The extracellular matrix is also a barrier to the host's immune system as it prevents the antibodies' recognition of bacterial antigens ${ }^{[100]}$. The proximity of different bacterial strains in the biofilm promotes a genetic exchange ${ }^{[11]}$. Indeed, the speed of conjugation within the biofilm is very fast, thus suggesting that the evolution by the horizontal transfer of genetic material occurs frequently, which makes the perfect medium for the acquisition of not only determinants of antibiotic resistance but also other virulence factors ${ }^{[101]}$. Acinetobacter is characterized by its important ability to acquire DNA from other species ${ }^{[2]}$.

It is clear that the resistance of desiccation depends on the ability of $A$. baumannii to maintain viability under the conditions of water limitations. Indeed, in Acinetobacter baylyi, a nonpathogenic relative of $A$. baumannii, capsular polysaccharides (Ps) promote survival during the periods of desiccation ${ }^{[102]}$. In A. baumannii biofilm, the ability of the capsule to retain water and the presence of a capsular Ps covering the cells play a prominent role in the resistance to desiccation ${ }^{[103]}$. Globally, $A$. baumannii has increased tolerance to the extracellular stresses within biofilm communities ${ }^{[16,59]}$, thus allowing this bacterium to persist and emerge, especially in hospitals, as one of the phenomenal nosocomial agents.

\section{Strategies of Prevention and Treatment of} A. baumannit Biofilm

Two strategies can be developed to fight against the biofilm: the prevention or the inhibition of biofilm formation and the dispersion of performed biofilm.

\section{Prevention}

The inhibition of biofilm formation by pre-adhesion intervention and biofilm formation may be useful.

The elaboration of anti-adhesive or anti-biofouling surfaces by using three different methods i.e., physical, chemical, or biological can be used to fight against the attachment of microorganisms and the formation of biofilm ${ }^{[104]}$.

The physical methods include the modification of the topography or the porosity of a material[104]. The surface chemical composition plays an important role in the adhesion of bacteria affected by the hydrophobicity and the electrostatic charge of the surface. Thus, the presence of specific chemical groups can also have an impact ${ }^{[104]}$. The addition of a hydrophilic coating (polymeric hydrophilic coatings) such as polyethylene glycol is used for building antifouling surfaces as they minimize the microbial adhesion ${ }^{[105]}$. 
Biological mechanisms are also conceivable to combat the development of a biofilm such as the use of non-pathogenic bacteria like Lactobacillus fermentum ${ }^{[106]}$. The presence of this bacterial strain allows the creation of an inhibition zone within the pathogenic biofilm probably because of the partial destruction of the cell membrane ${ }^{[106]}$.

On the contrary, A. baumannii contains a pgaABCD locus that encodes the proteins that synthesize cell-associated PNAG, which is the major compound of extracellular matrix in the biofilm of A. baumannii[38]. The deletion of the pga locus led to the loss of the strong biofilm phenotype ${ }^{[38]}$. Efforts are already under way to further investigate the potential of PNAG as a candidate vaccine against $A$. baumannii ${ }^{[38]}$. According to antibiotics, Beganovic et al. ${ }^{[107]}$ have tested the anti-biofilm effect of minocycline, polymyxin $B$, meropenem, and amikacin against $A$. baumannii. Minocycline prevented biofilm formation for $96 \%$ of isolates versus $54 \%$ for polymyxin $B, 29 \%$ for meropenem, and $29 \%$ for amikacin ${ }^{[107]}$.

\section{Dispersion}

The dispersion of performed biofilm is the treatment and the elimination of biofilms after their formation by antimicrobial agents, physical forces, and enzymes. In a study conducted by Golberg et al. ${ }^{[108]}$, algal Ps can be useful molecules. Algalsecreted Ps biomaterial patches and metal complex films (MCFs) are examined for their anti-A. baumannii and antiPseudomonas aeruginosa biofilm properties ${ }^{[108]}$. Polysaccharides moderately reduces biofilm formation; and the $\mathrm{Cu}-\mathrm{MCF}$ coating has a significant antibiofilm activity $(p<0.001)^{[108]}$. Quantitative analysis showed inhibition rates of 70\% and $98 \%$ in biofilm formation by A. baumannii, and $97 \%$ and $99 \%$ by Pseudomonas aeruginosa on the Ps and Cu-MCF coatings, respectively ${ }^{[108]}$. Biopanning was conducted with a peptide library on five XDR A. baumannii strains to find the antimicrobial peptides against A. baumannii growing in the planktonic and in the biofilm mode. These strains were later grown in a medium containing human blood (blood biopanning) and biofilms formed by these strains (biofilm biopanning) ${ }^{[109}$. Two peptides, namely N10 (from blood biopanning) and NB2 (from biofilm biopanning), were selected ${ }^{[109]}$. NB2 reduced the biofilm more efficiently (75\%) than $\mathrm{N} 10(50 \%)$ but the combination of the two peptides could function better than each peptide alone to prevent the biofilm formation of $A$. baumannif ${ }^{109]}$. In another study, the antibiofilm activity of various medicinal plants extracts was evaluated against the carbapenem-resistant strain of $A$. baumannii ${ }^{[110]}$. The results showed that the polar extract of kiwi (Actinidia deliciosa) and clove (Syzygium aromaticum) exhibit an effective antibiofilm activity ${ }^{[110]}$. The antibiofilm effect of Actinidia deliciosa extract on the extracellular matrix of $A$. baumannii showed that it reduces EPS, protein, and eDNA contents in the extracellular matrix $^{[110]}$. The antimicrobial and antibiofilm potential effects of cell-free supernatants obtained from Clostridium butyricum were also tested ${ }^{[111]}$. The results showed not only an inhibition effect against cell growth in the planktonic culture but also the inhibition of the biofilm development, dispersion of mature biofilms, and the suppression of the metabolic activity of biofilm cells ${ }^{[111]}$

Bacterial extracellular Ps have been shown to mediate many of the cell-to-cell and cell-to-surface interactions that are required for the formation, cohesion, and stabilization of bacterial biofilms ${ }^{[112]}$. Mutant strains unable to synthesize or export these EPS usually exhibit decreased adherence, decreased biofilm formation, and an increased sensitivity to be killed by biocides and host defenses ${ }^{[112]}$. These results highlight the importance of EPS in maintaining the integrity of the biofilm and in mediating the pathogenic potential of the biofilm lifestyle ${ }^{[112]}$. The dispersion or the disorganization of the EPS would be another strategy of combating biofilm ${ }^{[105]}$. There are specific enzymes that are capable of disrupting the EPS such as Ps lyases and DNases ${ }^{[113]}$, and Dispersin B (a glycoside hydrolase) which works by cleaving the polymers of PNAG that can disperse layers of EPS present on the medical devices ${ }^{[114,115]}$. This enzyme can offer a better result in combining with silver ${ }^{[116]}$ or with cefamandole nafate ${ }^{[117]}$.

QS is a complex system that regulates different virulence factors including biofilm formation in response to bacterial cell population density. The inhibition of this system also termed as 00, which may have a significant effect against biofilm. Several strategies have been considered to interrupt and/ or disrupt the bacterial QS system. These strategies include the inhibition of signal generation (acyl homoserine lactone synthesis), inhibition of signal diffusion, or inhibition of signal reception ${ }^{[118]}$. In the biofilm-growing cells, the homoserine lactone synthase (A1S_0109) of A. baumannii ATCC 17978 strain was over-expressed with respect to the planktonic cells ${ }^{[27]}$. Furthermore, many studies have demonstrated the utility of this anti-virulence and antibiofilm strategy. Chow et al. ${ }^{[119]}$ have detected a significant reduction of the biomass of $A$. baumanniiassociated biofilms by using 00 lactonase, obtained by directed evolution. Several plant extracts have been considered as anti-OS. For example, Commiphora leptophloeos (Burseraceae), Pityrocarpa moniliformis (Leguminosae), and Bauhinia acuruana (Leguminosae) extracts against Staphylococcus epidermidis ${ }^{[120]}$ and Terminalia catappa (Combretaceae). The methanolic extract inhibits QS-controlled violacein production and biofilms maturation of Chromobacterium violaceum and Pseudomonas aeruginosa, respectively ${ }^{[121]}$. The Australian macroalga Dilsea pulchra has the capability to produce a natural furanone that interfered with the bacterial signaling processes by its similarity in the structure to AHL molecules ${ }^{[122]}$. By binding competitively 
to the receptor, it is responsible for affecting the interaction of putative regulatory protein with AHL molecules.

All these possible strategies can be used to develop new drugs or modified medical devices by anchoring the antibiofilm molecules or create more effective disinfectants against the biofilm of $A$. baumannii.

\section{Conclusion}

A. baumannii has received much attention in recent years because of its success as a nosocomial pathogen along with its intrinsic and/or acquired resistance to the multiple classes of antibiotics and the ability to form biofilm in both biotic and abiotic surfaces. This ability plays a crucial role in the interactions between host and pathogen and in medical deviceassociated infections. It involves multiple cell signals, genetic determinants, and environmental factors. Currently, there is no close correlation between the genetic determinants implicated in the initiation of biofilm formation on the abiotic surfaces and those associated with the adherence to biotic surfaces.

With the development of resistance and persistence of $A$. baumannii, the research of effective strategies that procure antibacterial and antibiofilm properties is a real challenge. The abovementioned targets may be feasible and useful techniques for combating the A. baumannii biofilm. The targeting of the extracellular matrix polymerics and the OS system could offer very effective antibiofilm routes of action. Also, in basing on the medicinal and aromatic plants, we can develop a technique that is both useful and more secure.

We can also conclude that a combinatory strategy between an antimicrobial and an antibiofilm agent may provide better results by simultaneously offering a bactericidal and antibiofilm effect instead of using a single agent.

\section{Ethics}

Peer-review: Externally and internally peer-reviewed.

\section{Authorship Contributions}

Analysis or Interpretation: R.E., A.L., R.M., A.A., M.H., A.E., F.H., Literature Search: R.E., A.L., R.M., A.A., M.H., A.E., F.H., Writing: R.E., A.L., R.M., A.A., M.H., A.E., F.H.

Conflict of Interest: No conflict of interest was declared by the authors.

Financial Disclosure: The authors declared that this study received no financial support.

\section{References}

1. Pour NK, Dusane DH, Dhakephalkar PK, Zamin FR, Zinjarde SS, Chopade BA. Biofilm formation by Acinetobacter baumannii strains isolated from urinary tract infection and urinary catheters. FEMS Immunol Med Microbiol. 2011;62:328-38.
2. Peleg AY, Seifert H, Paterson DL. Acinetobacter baumannii: emergence of a successful pathogen. Clin Microbiol Rev. 2008;21:538-82.

3. Bergogne-Berezin $\mathrm{E}_{1}$ Joly-Guillou $\mathrm{M}-\mathrm{L}$, Towner KJ. Acinetobacter: microbiology, epidemiology, infections, management. CRC press, 1995.

4. Bergogne-Berezin E, Towner K. Acinetobacter spp. as nosocomial pathogens: microbiological, clinical, and epidemiological features. Clin Microbiol Rev. 1996;9:148.

5. Joly-Guillou M-L. Clinical impact and pathogenicity of Acinetobacter. Clin Microbiol Infect. 2005;11:868-73.

6. Magill SS, Edwards JR, Bamberg W, Beldavs ZG, Dumyati G, Kainer MA Lynfield R, Maloney M, McAllister-Hollod L, Nadle J. Multistate pointprevalence survey of health care-associated infections. N Engl J Med. 2014;370:1198-208

7. Lob SH, Hoban DJ, Sahm DF, Badal RE. Regional differences and trends in antimicrobial susceptibility of Acinetobacter baumannii. Int J Antimicrob Agents. 2016;47:317-23.

8. Rodríguez-Baño J, Marti S, Soto $\mathrm{S}$, Fernández-Cuenca $\mathrm{F}_{1}$ Cisneros JM, Pachón J, Pascual A, Martínez-Martínez L, McQueary C, Actis L. Biofilm formation in Acinetobacter baumannii: associated features and clinical implications. Clin Microbiol Infect. 2008;14:276-8.

9. Jawad A, Seifert H, Snelling A, Heritage J, Hawkey P. Survival of Acinetobacter baumannii on dry surfaces: comparison of outbreak and sporadic isolates. $J$ Clin Microbiol. 1998:36:1938-41.

10. Wendt C, Dietze B, Dietz E, Rüden H. Survival of Acinetobacter baumannii on dry surfaces. J Clin Microbiol. 1997;35:1394-7.

11. Donlan RM, Costerton JW. Biofilms: survival mechanisms of clinically relevant microorganisms. Clin Microbiol Rev. 2002;15:167-93.

12. Francolini I, Donelli G. Prevention and control of biofilm-based medicaldevice-related infections. FEMS Immunol Med Microbiol. 2010;59:227-38.

13. Jamal $M$, Ahmad $W$, Andleeb $S$, Jalil $F$, Imran $M$, Nawaz MA, Hussain T, Ali M, Rafiq M, Kamil MA. Bacterial biofilm and associated infections. J Chinese Med Assoc. 2018;81:7-11.

14. Batoni G, Maisetta G, Esin S. Antimicrobial peptides and their interaction with biofilms of medically relevant bacteria. Biochim Biophys Acta 2016;1858:1044-60.

15. Parsek MR, Singh PK. Bacterial biofilms: an emerging link to disease pathogenesis. Annu Rev Microbiol. 2003;57:677-701.

16. Greene C, Vadlamudi G, Newton D, Foxman B, Xi C. The influence of biofilm formation and multidrug resistance on environmental survival of clinical and environmental isolates of Acinetobacter baumannii. Am J Infect Control. 2016;44:e65-e71.

17. Gurung J, Khyriem AB, Banik A, Lyngdoh WV, Choudhury B, Bhattacharyya P. Association of biofilm production with multidrug resistance among clinical isolates of Acinetobacter baumannii and Pseudomonas aeruginosa from intensive care unit. Indian J Crit Care Med. 2013;17:214.

18. Tomaras AP, Dorsey CW, Edelmann RE, Actis LA. Attachment to and biofilm formation on abiotic surfaces by Acinetobacter baumannii: involvement of a novel chaperone-usher pili assembly system. Microbiology. 2003;149:347384.

19. Cevahir N, Demir M, Kaleli I, Gurbuz M, Tikvesli S. Evaluation of biofilm production, gelatinase activity, and mannose-resistant hemagglutination in Acinetobacter baumannii strains. J Microbiol Immunol Infect. 2008;41:5138.

20. Lee JC, Koerten $H$, Van den Broek $P$, Beekhuizen $H$, Wolterbeek $R$, Van den Barselaar M, Van der Reijden T, Van der Meer J, Van de Gevel J, Dijkshoorn L. Adherence of Acinetobacter baumannii strains to human bronchial epithelial cells. Res Microbiol. 2006;157:360-6.

21. Gaddy JA, Tomaras AP, Actis LA. The Acinetobacter baumannii 19606 OmpA protein plays a role in biofilm formation on abiotic surfaces and 
in the interaction of this pathogen with eukaryotic cells. Infect Immun. 2009;77:3150-60.

22. Martí $S$, Rodríguez-Baño J, Catel-Ferreira $M$, Jouenne T, Vila J, Seifert $H$, Dé E. Biofilm formation at the solid-liquid and air-liquid interfaces by Acinetobacter species. BMC Res Notes. 2011;4:5.

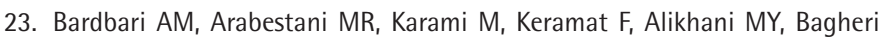
KP. Correlation between ability of biofilm formation with their responsible genes and MDR patterns in clinical and environmental Acinetobacter baumannii isolates. Microb Pathog. 2017;108:122-8.

24. Gaddy JA, Actis LA. Regulation of Acinetobacter baumannii biofilm formation. Future Microbiol. 2009;4:273_8.

25. Ivanković T, Goić-Barišić I, Hrenović J. Reduced susceptibility to disinfectants of Acinetobacter baumannii biofilms on glass and ceramic. Arhiv za higijenu rada i toksikologiju. 2017;68:99-107.

26. Kaliterna V, Kaliterna M, Hrenović J, Barišić Z, Tonkić M, Goic-Barisic I. Acinetobacter baumannii in Southern Croatia: clonal lineages, biofilm formation, and resistance patterns. Infect Dis. 2015;47:902-7.

27. Rumbo-Feal S, Gómez MJ, Gayoso C, Álvarez-Fraga L, Cabral MP, Aransay AM, Rodríguez-Ezpeleta N, Fullaondo A, Valle J, Tomás M. Whole transcriptome analysis of Acinetobacter baumannii assessed by RNA-sequencing reveals different mRNA expression profiles in biofilm compared to planktonic cells. PloS one. 2013;8:e72968.

28. Loehfelm TW, Luke NR, Campagnari AA. Identification and characterization of an Acinetobacter baumannii biofilm-associated protein. J Bacteriol. 2008;190:1036-44.

29. Han A, Li X, Huang B, Tsoi JK-H, Matinlinna JP, Chen Z, Deng DM. The effect of titanium implant surface modification on the dynamic process of initial microbial adhesion and biofilm formation. Int J Adhesion Adhesives. 2016;69:125-32.

30. Brossard KA, Campagnari AA. The Acinetobacter baumannii biofilmassociated protein plays a role in adherence to human epithelial cells. Infect Immun. 2012;80:228-33.

31. Proft T, Baker E. Pili in Gram-negative and Gram-positive bacteriastructure, assembly and their role in disease. Cell Mol Life Sci. 2009;66:613.

32. Gohl O, Friedrich A, Hoppert M, Averhoff B. The thin pili of Acinetobacter sp. strain BD413 mediate adhesion to biotic and abiotic surfaces. Appl Environ Microbiol. 2006;72:1394-401.

33. Harding CM, Hennon SW, Feldman MF. Uncovering the mechanisms of Acinetobacter baumannii virulence. Nat Rev Microbiol. 2018;16:91.

34. Shin J-H, Lee H-W, Kim S-M, Kim J. Proteomic analysis of Acinetobacter baumannii in biofilm and planktonic growth mode. J Microbiol. 2009;47:728-35.

35. de Breij A, Gaddy J, van der Meer J, Koning R, Koster A, van den Broek P, Actis L, Nibbering P, Dijkshoorn L. CsuA/BABCDE-dependent pili are not involved in the adherence of Acinetobacter baumannii ATCC 19606 to human airway epithelial cells and their inflammatory response. Res Microbiol. 2009;160:213-8.

36. Kishii $K$, Hamada M, Aoki $K$, Ito $K$, Onodera J, Ishii $Y$, Tateda K. Differences in biofilm formation and transcription of biofilm-associated genes among Acinetobacter baumannii clinical strains belonging to the international clone II lineage. J Infect Chemother. 2020.

37. Wright $M$, lovleva $A$, Jacobs $M$, Bonomo $R$, Adams M. Genome dynamics of multidrug-resistant Acinetobacter baumannii during infection and treatmen. Genome Med. 2016;8(1):26.

38. Choi AH, Slamti L, Avci FY, Pier GB, Maira-Litrán T. The pgaABCD locus of Acinetobacter baumannii encodes the production of poly- $\beta-1-6-\mathrm{N}-$ acetylglucosamine, which is critical for biofilm formation. J Bacteriol. 2009;191:5953-63.

39. Xiang J, Sun Z, Yang $X$, Huan J. Changes in expression of gene aba I in biofilm of Acinetobacter baumanniistrains isolated from burn patients. Chin J Burns. 2012;28:101-5.
40. Bentancor LV, O'Malley JM, Bozkurt-Guzel C, Pier GB, Maira-Litrán T. Poly$\mathrm{N}$-acetyl- $\beta-(1-6)$-glucosamine is a target for protective immunity against Acinetobacter baumannii infections. Infect Immun. 2012;80:651-6.

41. Roca Subirà I, Espinal P, Vila-Farrés X, Vila Estapé J. The Acinetobacter baumannii Oxymoron: Commensal Hospital Dweller Turned Pan-DrugResistant Menace. Front Microbiol. 2012;3.

42. Choi CH, Lee EY, Lee YC, Park TI, Kim HJ, Hyun SH, Kim SA, Lee S-K, Lee JC. Outer membrane protein 38 of Acinetobacter baumannii localizes to the mitochondria and induces apoptosis of epithelial cells. Cell Microbiol. 2005;7:1127-38.

43. Longo $F$, Vuotto $C$, Donelli G. Biofilm formation in Acinetobacter baumannii. New Microbiol. 2014;37:119-27.

44. Choi CH, Lee JS, Lee YC, Park TI, Lee JC. Acinetobacter baumannii invades epithelial cells and outer membrane protein A mediates interactions with epithelial cells. BMC Microbiology. 2008;8:216.

45. Lee H-W, Koh YM, Kim J, Lee J-C, Lee Y-C, Seol S-Y, Cho D-T, Kim J. Capacity of multidrug-resistant clinical isolates of Acinetobacter baumannii to form biofilm and adhere to epithelial cell surfaces. Clin Microbiol Infect. 2008;14:49-54.

46. Rao RS, Karthika RU, Singh $S$, Shashikala $P$, Kanungo $R$, Jayachandran $\mathrm{S}$, Prashanth K. Correlation between biofilm production and multiple drug resistance in imipenem resistant clinical isolates of Acinetobacter baumannii. Indian J Med Microbiol. 2008;26:333.

47. Diggle SP, Griffin AS, Campbell GS, West SA. Cooperation and conflict in quorum-sensing bacterial populations. Nature. 2007;450:411.

48. Uroz S, Dessaux Y, Oger P. Quorum Sensing and Quorum Quenching: The Yin and Yang of Bacterial Communication. Chem Biol Chem. 2009;10:205-16.

49. Bassler BL. Small talk: cell-to-cell communication in bacteria. Cell. 2002;109:421-4.

50. Waters CM, Bassler BL. Quorum sensing: cell-to-cell communication in bacteria. Annu Rev Cell Dev Biol. 2005;21:319-46.

51. Whitehead NA, Barnard AML, Slater H, Simpson NJL, Salmond GPC. Quorumsensing in Gram-negative bacteria. FEMS Microbiol Rev. 2001;25:365-404.

52. Bhargava N, Sharma P, Capalash N. Quorum sensing in Acinetobacter: an emerging pathogen. Crit Rev Microbiol. 2010;36:349-60.

53. Kalia VC. Quorum sensing vs quorum quenching: a battle with no end in sight. Springer, 2015.

54. Anbazhagan D, Mansor M, Yan GOS, Yusof MYM, Hassan H, Sekaran SD. Detection of quorum sensing signal molecules and identification of an autoinducer synthase gene among biofilm forming clinical isolates of Acinetobacter spp. PloS one. 2012;7:e36696.

55. Guo $H$, Xiang J. Influences of abaR gene on biofilm formation of Acinetobacter baumannii. Chin J Burns. 2017;33:200-5.

56. Luo L-m, Wu L-j, Xiao Y-I, Zhao D, Chen Z-x, Kang M, Zhang Q, Xie Y. Enhancing pili assembly and biofilm formation in Acinetobacter baumannii ATCC 19606 using non-native acyl-homoserine lactones. BMC microbiology. 2015;15:62.

57. Saipriya K, Swathi C, Ratnakar K, Sritharan V. Quorum-sensing system in Acinetobacter baumannii: a potential target for new drug development. J Appl Microbiol. 2020;128:15-27.

58. Greene $\mathrm{C}, \mathrm{Wu} J$, Rickard AH, Xi C. Evaluation of the ability of Acinetobacter baumannii to form biofilms on six different biomedical relevant surfaces. Lett Appl Microbiol. 2016;63:233-9.

59. Jones DS, Gorman SP. Medical Device Composition and Biological Secretion Influences on Biofilm Formation. Biofilms, Infection, and Antimicrobial Therapy: CRC Press, 2005:62-81.

60. Gilmore BF, Gorman SP. Antimicrobial devices. Russell, Hugo \& Ayliffe's: Principles and Practice of Disinfection, Preservation and Sterilization. 2013:500-13. 
61. Nath $\mathrm{N}$, Hyun J, Ma H, Chilkoti A. Surface engineering strategies for control of protein and cell interactions. Surface Sci. 2004;570:98-110.

62. Pamuła E, De Cupere V, Dufrêne YF, Rouxhet PG. Nanoscale organization of adsorbed collagen: Influence of substrate hydrophobicity and adsorption time. J Colloid Interface Sci. 2004;271:80-91.

63. Azelmad K, Hamadi F, Mimouni R, Amzil K, Latrache H, Mabrouki M, El Boulani A. Adhesion of Staphylococcus aureus and Staphylococcus xylosus to materials commonly found in catering and domestic kitchens. Food Control. 2017;73:156-63.

64. Mittelman MW. Adhesion to biomaterials. Bacterial adhesion: molecular and ecological diversity New York: Wiley-Liss, Inc. 1996:89-127.

65. O'Toole G, Kaplan HB, Kolter R. Biofilm formation as microbial development. Annu Rev Microbiol. 2000;54:49-79.

66. De Silva PM, Chong P, Fernando DM, Westmacott G, Kumar A. Effect of incubation temperature on antibiotic resistance and virulence factors of Acinetobacter baumannii ATCC 17978. Antimicrob Agents Chemother. 2018;62:e01514-17.

67. Eze EC, El Zowalaty ME. Combined Effects Of Low Incubation Temperature, Minimal Growth Medium, And Low Hydrodynamics Optimize Acinetobacter baumannii Biofilm Formation. Infect Drug Resistance. 2019;12:3523.

68. Mussi MA, Gaddy JA, Cabruja M, Arivett BA, Viale AM, Rasia R, Actis LA. The opportunistic human pathogen Acinetobacter baumannii senses and responds to light. J Bacteriol. 2010;192:6336-45.

69. Spormann A. Physiology of microbes in biofilms. Bacterial biofilms: Springer, 2008:17-36.

70. Martinez LR, Casadevall A. Cryptococcus neoformans biofilm formation depends on surface support and carbon source and reduces fungal cell susceptibility to heat, cold, and UV light. Appl Environ Microbiol. 2007;73:4592-601.

71. Nucleo E, Steffanoni L, Fugazza G, Migliavacca R, Giacobone E, Navarra A, Pagani L, Landini P. Growth in glucose-based medium and exposure to subinhibitory concentrations of imipenem induce biofilm formation in a multidrug-resistant clinical isolate of Acinetobacter baumannii. BMC Microbiol. 2009;9:270.

72. Gentile V, Frangipani $E$, Bonchi $C$, Minandri F, Runci $F$, Visca P. Iron and Acinetobacter baumannii biofilm formation. Pathogens. 2014;3:704-19.

73. Nwugo CC, Arivett BA, Zimbler DL, Gaddy JA, Richards AM, Actis LA. Effect of ethanol on differential protein production and expression of potential virulence functions in the opportunistic pathogen Acinetobacter baumannii. PLoS One. 2012;7:e51936.

74. Decré DJRFdL. Acinetobacter baumannii et résistance aux antibiotiques: un modèle d'adaptation. REVUE FRANCOPHONE DES LABORATOIRES. 2012;2012:43-52.

75. Bocanegra-Ibarias P, Pena-López C, Camacho-Ortiz A, Llaca-Díaz J, SilvaSánchez J, Barrios H, Garza-Ramos U, Rodríguez-Flores AM, Garza-González E. Genetic characterisation of drug resistance and clonal dynamics of Acinetobacter baumannii in a hospital setting in Mexico. Int J Antimicrob agents. 2015;45:309-13.

76. El-Shazly S, Dashti A, Vali L, Bolaris M, Ibrahim ASJIJolD. Molecular epidemiology and characterization of multiple drug-resistant (MDR) clinical isolates of Acinetobacter baumannii. Int J Infect Dis. 2015;41:42-9.

77. Laktib A, Hassi M, Hamadi F, Mimouni R, Bourouache M, Bihadassen B, Alla AA. Identification and antibiotic resistance of nosocomial bacteria isolated from the hospital environment of two intensive care units. Moroccan J Biol. 2018.

78. Eliopoulos GM, Maragakis LL, Perl TMJCid. Acinetobacter baumannii: epidemiology, antimicrobial resistance, and treatment options. Antimicrob Resist. 2008;46:1254-63.

79. Garcia-Garmendia J-L, Ortiz-Leyba C, Garnacho-Montero J, JiménezJiménez F-J, Pérez-Paredes $C$, Barrero-Almodóvar AE, Miner MG. Risk factors for Acinetobacter baumannii nosocomial bacteremia in critically ill patients: a cohort study. Clin Infect Dis. 2001;33:939-46.

80. Azizi O, Shakibaie MR, Modarresi F, Shahcheraghi F. Molecular detection of class-D OXA carbapenemase genes in biofilm and non-biofilm forming clinical isolates of Acinetobacter baumannii. Jundishapur J Microbiol. $2015 ; 8$.

81. Safari M, Saidijam M, Bahador A, Jafari R, Alikhani MYJJorihs. High prevalence of multidrug resistance and metallo-beta-lactamase $(\mathrm{M} \beta \mathrm{L})$ producing Acinetobacter baumannii isolated from patients in ICU wards, Hamadan, Iran. J Res Health Sci. 2013;13:162-7.

82. Manchanda V, Sanchaita S, Singh N. Multidrug resistant Acinetobacter. J Glob Infect Dis 2: 291-304. 2010.

83. Babapour E, Haddadi A, Mirnejad R, Angaji S-A, Amirmozafari N. Biofilm formation in clinical isolates of nosocomial Acinetobacter baumannii and its relationship with multidrug resistance. Asian Pac J Trop Med Biomed. 2016;6:528-33.

84. Rahbar MR, Rasooli I, Gargari SLM, Amani J, Fattahian Y. In silico analysis of antibody triggering biofilm associated protein in Acinetobacter baumannii. J Theor Biol. 2010;266:275-90.

85. Nahar A, Anwar S, Miah MRA. Association of biofilm formation with antimicrobial resistance among the Acinetobacter species in a tertiary care hospital in Bangladesh. J Med. 2013;14:28-32.

86. Badave GK, Kulkarni D. Biofilm producing multidrug resistant Acinetobacter baumannii: an emerging challenge. J clin diagn res. 2015;9:DC08.

87. Alav I, Sutton JM, Rahman KM. Role of bacterial efflux pumps in biofilm formation. J Antimicrob Chemother. 2018;73:2003-20.

88. He X, Lu F, Yuan F, Jiang D, Zhao P, Zhu J, Cheng H, Cao J, Lu G. Biofilm formation caused by clinical Acinetobacter baumannii isolates is associated with overexpression of the AdeFGH efflux pump. Antimicrob Agents Chemother. 2015;59:4817-25.

89. Chen H, Cao J, Zhou C, Liu H, Zhang X, Zhou T. Biofilm formation restrained by subinhibitory concentrations of tigecyclin in Acinetobacter baumannii is associated with downregulation of efflux pumps. Chemotherapy. 2017:62:128-33.

90. Sharma A, Sharma R, Bhattacharyya T, Bhando T, Pathania R. Fosfomycin resistance in Acinetobacter baumannii is mediated by efflux through a major facilitator superfamily (MFS) transporter-AbaF. J Antimicrob Chemotherap. 2016;72:68-74.

91. Lewis K. Riddle of biofilm resistance. Antimicrob Agents Chemother 2001;45:999-1007.

92. Young DM, Parke D, Ornston LN. Opportunities for genetic investigation afforded by Acinetobacter baylyi, a nutritionally versatile bacterial species that is highly competent for natural transformation. Annu Rev Microbiol. 2005;59:519-51.

93. Tanner WD, Atkinson RM, Goel RK, Toleman MA, Benson LS, Porucznik CA, VanDerslice JA. Horizontal transfer of the blaNDM-1 gene to Pseudomonas aeruginosa and Acinetobacter baumannii in biofilms. FEMS Microbiol Lett. 2017;364.

94. Grassi L, Maisetta G, Esin S, Batoni G. Combination strategies to enhance the efficacy of antimicrobial peptides against bacterial biofilms. Front Microbiol. 2017;8:2409.

95. Reffuveille $F$, de la Fuente-Núñez $C$, Mansour S, Hancock RE. A broadspectrum antibiofilm peptide enhances antibiotic action against bacterial biofilms. Antimicrob Agents Chemother. 2014;58:5363-71.

96. Han X, Li Q, Shen L, Hu D, Qu Y. Correlation between the biofilm-forming ability, biofilm-related genes and antimicrobial resistance of Acinetobacter baumannii. Chin Crit Care Med. 2014;26:639-43.

97. Oi L, Li H, Zhang C, Liang B, Li J, Wang L, Du X, Liu X, Qiu S, Song H. Relationship between antibiotic resistance, biofilm formation, and biofilm- 
specific resistance in Acinetobacter baumannii. Frontiers in microbiology. $2016 ; 7: 483$

98. Yoon E-J, Chabane YN, Goussard S, Snesrud E, Courvalin P, Dé E, GrillotCourvalin C. Contribution of resistance-nodulation-cell division efflux systems to antibiotic resistance and biofilm formation in Acinetobacter baumannii. MBio. 2015;6:e00309-15.

99. Khoury AE, Lam K, Ellis $B$, Costerton JW. Prevention and control of bacterial infections associated with medical devices. Am Soc Artif Intern Organs J. 1992;38:M174-8.

100. Roux A, Ghigo J-M. Les biofilms bactériens. Bulletin de I'Académie vétérinaire de France. 2006.

101. Watnick P, Kolter R. Biofilm, city of microbes. J Bacteriol. 2000;182:2675-9.

102. Ophir T, Gutnick DL. A role for exopolysaccharides in the protection of microorganisms from desiccation. Appl Environ Microbiol. 1994;60:740-5.

103. Espinal P, Marti S, Vila J. Effect of biofilm formation on the survival of Acinetobacter baumannii on dry surfaces. J Hosp Infect. 2012;80:56-60.

104. Fabre H. Contributions des propriétés physico-chimiques de surfaces de titane sur l'adhérence de microorganismes: application aux chambres implantables. Le Mans; 2017.

105. Roy R, Tiwari M, Donelli G, Tiwari V. Strategies for combating bacterial biofilms: A focus on anti-biofilm agents and their mechanisms of action. Virulence. 2018;9:522-54.

106. Rybalchenko OV, Bondarenko VM, Orlova OG, Markov AG, Amasheh S. Inhibitory effects of Lactobacillus fermentum on microbial growth and biofilm formation. Arch Microbiol. 2015;197:1027-32.

107. Beganovic M, Luther MK, Daffinee KE, LaPlante KLDm, disease i. Biofilm prevention concentrations (BPC) of minocycline compared to polymyxin $\mathrm{B}$, meropenem, and amikacin against Acinetobacter baumannii. Diagn Microbiol Infect Dis. 2019;94:223-6.

108. Golberg K, Emuna N, Vinod T, Van Moppes D, Marks RS, Arad SM, Kushmaro A. Novel Anti-Adhesive Biomaterial Patches: Preventing Biofilm with Metal Complex Films (MCF) Derived from a Microalgal Polysaccharide. Advanced Materials Interfaces. 2016;3:1500486.

109. Irani N, Basardeh E, Samiee F, Fateh A, Shooraj F, Rahimi A, Shahcheraghi $F$, Vaziri $F$, Masoumi M, Pazhouhandeh M. The inhibitory effect of the combination of two new peptides on biofilm formation by Acinetobacter baumannii. Microb Pathog. 2018;121:310-7.

110. Tiwari V, Tiwari D, Patel V, Tiwari M. Effect of secondary metabolite of Actinidia deliciosa on the biofilm and extra-cellular matrix components of Acinetobacter baumannii. Microb Pathog. 2017;110:345-51.
111. Shin D-S, Eom Y-BJAoM. Antimicrobial and antibiofilm activities of Clostridium butyricum supernatant against Acinetobacter baumannii. Archives Microbiol. 2020:1-10.

112. Rendueles 0, Kaplan JB, Ghigo JM. Antibiofilm polysaccharides. Environ Microbiol. 2013;15:334-46.

113. Stewart P. Prospects for anti-biofilm pharmaceuticals. Pharmaceuticals. 2015;8:504-11.

114. Izano EA, Amarante MA, Kher WB, Kaplan JB. Differential roles of poly$\mathrm{N}$-acetylglucosamine surface polysaccharide and extracellular DNA in Staphylococcus aureus and Staphylococcus epidermidis biofilms. Appl Environ Microbiol. 2008;74:470-6.

115. Kaplan JB. Therapeutic potential of biofilm-dispersing enzymes. Int J Artif Organs. 2009;32:545-54.

116. Gawande PV, Clinton AP, LoVetri K, Yakandawala N, Rumbaugh KP, Madhyastha $S$. Antibiofilm efficacy of Dispersin $B^{\circledR}$ wound spray used in combination with a silver wound dressing. Microbiol insights. 2014;7:MBI. S13914.

117. Donelli G, Francolini I, Romoli D, Guaglianone E, Piozzi A, Ragunath C, Kaplan J. Synergistic activity of dispersin B and cefamandole nafate in inhibition of staphylococcal biofilm growth on polyurethanes. Antimicrob Agents Chemother. 2007;51:2733-40.

118. Bouyahya A, Dakka N, Et-Touys A, Abrini J, Bakri Y. Medicinal plant products targeting quorum sensing for combating bacterial infections. Asian Pac J Trop Med. 2017;10:729-43.

119. Chow JY, Yang Y, Tay SB, Chua KL, Yew WS. Disruption of biofilm formation by the human pathogen Acinetobacter baumannii using engineered quorumquenching lactonases. Antimicrob Agents Chemother. 2014;58:1802-5.

120.da Silva Trentin D, Giordani RB, Zimmer KR, Da Silva AG, Da Silva MV, dos Santos Correia MT, Baumvol IJR, Macedo AJ. Potential of medicinal plants from the Brazilian semi-arid region (Caatinga) against Staphylococcus epidermidis planktonic and biofilm lifestyles. J Ethnopharmacol. 2011;137:327-35.

121.Taganna JC, Quanico JP, Perono RMG, Amor EC, Rivera WL. Tanninrich fraction from Terminalia catappa inhibits quorum sensing (OS) in Chromobacterium violaceum and the QS-controlled biofilm maturation and LasA staphylolytic activity in Pseudomonas aeruginosa. J Ethnopharmacol. 2011;134:865-71.

122.Givskov M, de Nys R, Manefield M, Gram L, Maximilien R, Eberl L, Molin S, Steinberg PD, Kjelleberg S. Eukaryotic interference with homoserine lactone-mediated prokaryotic signalling. J Bacteriol. 1996;178:6618-22. 